\title{
Groundwater Control Issues in Transportation Engineering: A Short Review of Dewatering Methods and Lessons Learned
}

\author{
M. L. Angel, S. Johnston, K. O’Steen, C. Brown* and T. Sando \\ School of Engineering, University of North Florida, 1 UNF Drive, Jacksonville, FL 32224
}

Received 26 August 2015; Accepted 25 October 2015

\begin{abstract}
Areas that once were deemed unsuitable for construction due to a high water table are now being developed to meet the needs of an increasing population. With the decline in land availability to build or expand highway networks above ground, underground facilities, such as mass-transit lines, may represent the future of transportation. Underground structures naturally require the control of groundwater to complete construction. A review of common dewatering systems and methods used in the construction of transportation facilities found that similar techniques are used in other industries. Also, scant few case studies document dewatering problems although they represent a key component of common construction claims in the civil engineering industry. A common thread among all construction initiatives is the need for thorough subsurface site investigation. The uncertainty of subsurface conditions related to groundwater issues has resulted in insurance claims and litigation reaching disproportionately high numbers in civil engineering construction. Better assessments of hydrogeological formations may help to mitigate potential groundwater control problems.
\end{abstract}

Keywords: Dewatering, Dewatering methods, engineering design, construction claims

\section{Introduction}

Many civil engineering construction projects typically require the excavation of soil. Depending on the geographical location of the project and depth of excavation, groundwater may be encountered. Areas that were once deemed unsuitable for construction due to a high water table are now being developed to meet the needs of an increasing population. As population numbers rise, the need for transportation infrastructure to accommodate traffic volumes has increased. With the decline in land availability to build or expand highway networks above ground, underground facilities, such as mass-transit lines, may represent the future of transportation. Underground structures naturally require the control of groundwater to complete construction. Dewatering is a process for the temporary removal of subsurface water to enable construction to be completed under dry conditions. Project specific in nature, dewatering techniques depend largely on the scope of the project, prevailing soils, hydrological characteristics, degree of difficulty, and associated cost. Controlling groundwater can be costly, not only during construction, but also from resulting damages to infrastructure or property if not done carefully. Consequently, insurance claims associated with subsurface site conditions are disproportionately high. Abdul-Rahman et al. [1] concluded that dewatering or drainage issues led to $8.2 \%$ of construction delay claims in Malaysia, based upon industry surveys. Claim percentages as high as $50 \%$ have been noted in Canada (Peaker [2]). Dewatering processes can also hinder the completion of a

\footnotetext{
* E-mail address: christopher.j.brown@unf.edu
}

project if inadequately planned (Serag et al. [3]). The public transportation construction industry is a multi-billion dollar industry where costly delays can add up quickly. This short review paper explores common dewatering techniques currently in use for transportation engineering projects, common problems that arise, and lessons learned in the industry.

\section{Background}

One of the earliest recorded dewatering examples in modern times occurred in 1830s England with the construction of the Kilsby railroad tunnel where a series of shafts and boreholes, known today as sumps and wells, were pumped to remove water from a large area of quicksand encountered during construction (Ratay [4]). A series of 13 engine driven wells were used to dewater the site constituting the first documented well system approach to controlling groundwater during construction (Powers et al. [5]). Subsequently, the treatment of saturated sandy soils by steam-powered pumps, French drains, gravel, sheeting, and sandbags dominated the construction industry until the early 1900s (Ratay [4]). Wellpoints with electric submersible pumps then gained popularity with successful dewatering of sandy soils up to the mid-1920s (Powers et al. [5]). At that time, Thomas F. Moore, a designer and manufacturer of excavator equipment used in trenching, introduced the first effective wellpoint design for dewatering in fine-grained soils (Ratay [4]).

During the $1800 \mathrm{~s}$, in the midst of the industrial revolution, the need for reliable infrastructure to transport 
people and goods led to a surge of groundbreaking civil engineering projects in the United States (U.S.). Such engineering landmarks included the Erie Canal (1825), the Croton Aqueduct (1842), the Transcontinental Railroad (1869), the Eads Bridge (1874), the Brooklyn Bridge (1883), the New York City Subway (1904), and the Holland Tunnel in 1927 (Brown [6]). Many techniques used at the time in the U.S. for construction and dewatering were already being practiced in Europe (Brown [6]). Moreover, many early American engineers first trained in Europe before leading the design and construction efforts of these landmark structures (Brown [6]). While the design elements appeared to be sound, construction methods were more or less, trialand-error methods with costly results in loss of life. Up to the 1940s, controlling groundwater was primarily based on field experience, more of an art than a science (Ratay [4]). With the integration of soil mechanics and hydrology, a more scientific approach to dewatering changed the construction industry. Today, pre-designed dewatering models incorporate science and technology and allow more complex underground construction projects to be possible. Although modern theory has replaced much of the art, field experience still plays an important role in identifying unanticipated problems that can never be fully emulated by computer models.

Dewatering methods are project specific by nature, and are generally a critical path element in construction. A thorough understanding of the subsurface rock and soil conditions at the site is paramount in the development and implementation of a successful dewatering operation (Ratay [4]). Identifying the soil types, densities, permeability, stratigraphy and consolidation through testing is the first step. Secondly, the hydrological characteristics of the site must be defined to determine the source of the water and expected water level during dewatering (Ratay [4]). Other factors to consider are surrounding structures, local climate, and time of year, any of which could affect surficial groundwater levels. Effects of dewatering on adjacent structures such as foundation and structural damage due to differential settlement must also be considered, especially in urban areas and historic districts. A cost benefit analysis can often be the deciding factor in the dewatering design. All of these factors must be taken into account to determine the most effective dewatering system that will accomplish the primary construction goal.

Published literature on case studies involving successful dewatering systems used in the construction industry are few, and even scarcer for transportation related construction projects. Typically, only catastrophes are highlighted (Ren et al. [7]) among published data. Literature on large-scope transportation efforts often concentrate on engineering elements other than groundwater control measures, which are essential for the success of the project. Kiziltas and Akinci [8] argue for better documentation of case study data to improve construction cost estimates and limit potential problems.

\section{Dewatering Techniques}

Dewatering systems used today vary in type and complexity. Yet many systems are similar, although greatly enhanced, to those employed two centuries ago. Transportation facilities, such as roads, bridges, tunnels, and canals are essential to society worldwide. For a project to be completed safely and successfully, the degree of dewatering required often corresponds with scale of construction.

\section{Open Pumping and Trench Methods}

The simplest dewatering technique involves the use of a sump pump placed in a swallow ditch to remove surficial groundwater (Ratay [4]). This method is useful for small excavations, and is often used in the dewatering of roadside ditches for short-term construction. Water can effectively be conveyed outside the area of excavation to a holding pond, enclosed drainage system, or a lower point downstream, until construction is complete. Removing water during construction by pumping has been a practical method for over two-hundred years. A variety of pumps are available today with a wide range of flow capacities. For example, a portable gasoline-powered wet priming pump with suction and discharge sizes of $5 \mathrm{~cm}$ to $7.5 \mathrm{~cm}$ diameter can operate for several hours on a tank of gas and remove up to 950 L/min (Lescohier [9]). Generally, a pre-designed dewatering plan is not required for this method. However, the amount of water to be removed and duration of pumping time (hours or days) dictate the type of pump and pumping rates required to meet the needs of the project.

Sumps pumps are also used to augment larger dewatering systems to collect surface water from rain or groundwater seepage, and remain an important tool in construction (Ratay [4]). Surface water in an excavation must be removed quickly to prevent work delays. However, the use of sumps are not limited to small scale construction. At one time, in New York, sumps were used in most excavations below the water table referred to as "peel the onion", where soil was dewatered and removed in layers to the desired depth (Ratay [4]).

Perforated drainage pipe encased in gravel, or French drains, can be used at the toe of slope to collect surface water and convey it to a sump. A similar system can be utilized in surface roads to control groundwater intrusion into the roadway base and subbase materials postconstruction. Over time, cracks in flexible pavement can occur due to increased traffic and heavier loads, allowing water seepage into the underlying infrastructure foundation. In areas where fairly high water tables exist and cost or other circumstances prohibit the construction of elevated or builtup roadway sections, subsurface drainage systems can prevent infrastructure failure resulting from subsurface saturation. Cyr and Chiasson [10] examined the use of perforated drain pipes at varying locations and depths below the curb and gutter for at-grade roadways in Canada. The perforated drain pipe system proved effective in shortening the drainage period of subsurface water at or near the roadway base layer, thus preventing damage. However, a high percentage of saturation remained present in the lower gravel base during heavy daily rains (Cyr \& Chiasson [10]). A concern for transportation officials and engineers, saturated roadway foundations can, at a minimum, lead to roadway failure, and in some parts of the U.S, extreme undermining may produce sinkholes.

\section{Well Systems}

Wellpoint dewatering systems are a preferred choice for a range of construction projects where moderate to heavy excavation is required in low-permeability soils, and shallow aquifer dewatering is required. A wellpoint is essentially a small well, up to $6.3 \mathrm{~cm}$ in diameter, with a screened opening at the bottom, and connected to a vacuum header pipe at the surface for effective suction lifts up to $4.6 \mathrm{~m}$ (Powers et al. [5]). A pump connects the header pipes to draw down the water level. They are highly effective in lowflow, low-permeability soils where larger wells are unable to 
maintain design high pumping rates, but are also suitable for high-flow conditions with larger pipe diameters and highercapacity intake screens (Ratay [4]). Dewatering systems may consist of a few to several thousand wellpoints, and are desirable when geological characteristics warrant close spacing of devices (Ratay [4]). A single wellpoint can remove as little as a fraction of a liter up to $400 \mathrm{~L} / \mathrm{min}$ efficiently. If needed, a multi-tiered system can be constructed to achieve greater drawdowns. Installation and maintenance of wellpoint systems can be very expensive. Other disadvantages include the amount of pipe required for the system which can limit mobility on a construction site, and can be easily damaged by heavy equipment. Additionally, hard water can also cause clogging of wellpoints due to mineral buildup in pipes.

An alternative to wellpoints are deep well dewatering systems. Initially developed for oil exploration and water supply wells, deep wells have become a practical choice today due to better equipment and installation methods (Powers et al. [5]). A deep well uses a submersible line shaft turbine pump to drain water from $7 \mathrm{~m}$ to over $60 \mathrm{~m}$ below the surface with flow capacities of up to several thousand liters per minute (Driscoll [11]). Wells can vary from 75 $\mathrm{mm}$ to up to $1.2 \mathrm{~m}$ in diameter. Because the duration of pumping can greatly add to the overall cost of dewatering, wells are often the most cost effective solution due to their high flow capacities, if soil conditions are favorable (Ratay [4]; Driscoll [11]). One disadvantage with deep well systems is the amount of power required to operate the pumps, which can be a factor when working in areas where access to the power grid is not an option. As a result, large on-site generators are generally required for either primary or backup power to ensure continuous operation. Proper monitoring and maintenance of wells are also important. During long periods of pumping, fine materials can be pulled through the well screens and cause clogging (Jurado et al. [12]).

Complex dewatering systems are typically designed prior to construction based on the amount of drawdown required and subsurface soil profile at the project site. However, design expectations are not always realized in the field. One example is the construction of the New Olmsted Locks in the Ohio River. Although the dewatering system was successful, the fully penetrating deep wells exhibited greater variations in flow rates to river stages than the design anticipated. (Mansur \& Durrett [13]). These observations were attributed to the complex stratigraphy in the confined aquifer believed to contain fragmented alternating pervious and impervious layers potentially effecting water levels in the piezometers.

\section{Groundwater Cutoff Methods}

\section{Steel Sheet Piling}

Construction of bridges over waterways has been occurring in the U.S. since the mid to late nineteenth century. However, these did not proceed without challenges. Creating a dry area to construct a pier or abutment foundation in open water has been and remains a difficult undertaking. Cofferdams are used for dewatering in these cases.

One of the first large-scale bridge projects to use cofferdams was the construction of the Eads Bridge stretching over the Mississippi River in St. Louis, Missouri, 1867-1874 (Brown [6]). In 1869, the west abutment was constructed using cofferdams extending to the bedrock, 12 $\mathrm{m}$ below the mean high water table. Bedrock on the east abutment was considerably lower, up to $28.5 \mathrm{~m}$ deeper than the west bank. What was then a new and innovative dewatering technique, pneumatic caissons, currently being used in Europe, were used to construct the deep pier and east abutment foundations (Brown [6]). Large precast iron pipes were submersed to bedrock, capped with an air lock, and injected with compressed air to construct a deep river cofferdam. Crews descended into chambers to excavate the riverbed, and build the foundations. Many workers developed what is called "caisson sickness", later known as the bends, or decompression sickness, by ascending from the caissons too quickly (Brown [6]). Fifteen men died and many others were injured using this construction method before precaution measures could be implemented. Similar experiences with caisson sickness were also reported during the construction of the Brooklyn Bridge around the same time in 1872 (Brown [6]).

Today, steel sheet piling is commonly used for deep foundation cofferdams. Continuous interlocking sheet piling is an effective tool in stopping the horizontal flow of groundwater, and is also used in land based construction to minimize the scope of a dewatering program (Ratay [4]). The sheeting is typically driven down to an impervious layer to prevent piping of water beneath the pilings. If designed and installed correctly, interlock seepage can be low. However, in clean permeable soils, leakage can be large if interlock tension is insufficient. For open water uses, interlocks must be fully sealed.

Preventing piping beneath the pilings was paramount in the cofferdam construction of the New Olmsted Locks in the Ohio River, one of the largest cofferdams ever constructed in the U.S (Mansur \& Durrett [13]). The Olmsted Lock cofferdam consisted a continuous wall of 50 massive sheet pile cells, $19 \mathrm{~m}$ in diameter, connected together by smaller arc shaped sheet pile cells, surrounding an area of excavation of $30 \mathrm{~m}$ deep. Sealed deep dewatering wells with submersible vacuum pumps, were required in each coffercell and connecting arc cell to lower the groundwater level to 1.5 $\mathrm{m}$ below the excavation and prevent piping. Some seepage was expected since sheet piling is not airtight. The engineers assumed that the larger circular coffercells would leak more than the connecting arc cells and designed the pumping rates accordingly. However, after the initial pump test, the opposite occurred (Mansur \& Durrett [13]). Leakage was greater in the smaller arc cells due to inadequate interlock tension resulting from the piling shape. Overall, the dewatering system consisting of a total of 250 wells (99 in the cofferdam), performed as designed.

As an alternative to traditional sheet pile cofferdams, environmentally friendly portable cofferdams offer the latest in dewatering technology for shallow applications up to 3.6 $\mathrm{m}$ in depth. This system employs an impervious reinforced waterproof polyvinyl chloride liner attached to a freestanding, welded tubular steel support system (Keeping water out [14]). With the Nation's infrastructure aging, portable lightweight cofferdams could present a cost effective alternative to traditional sheet piling for bridge pier rehabilitation.

\section{Ground Freezing}

Another technique for halting horizontal groundwater flow is by means of ground freezing. Ground freezing results in a frozen soil mass, essentially an earthen cofferdam that provides excavation support as well as blocking groundwater (Ratay [4]). This technique, although 
expensive, may present the most economic method for underground construction in saturated soils where space limits the feasibility of other dewatering methods. To freeze the soil, a series of external pipes are drilled into the ground to create a wall in a specific shape determined by job requirements. An internal drop pipe is placed into the pipe and a refrigerant, usually calcium chloride brine, is pumped through the pipes to freeze the ground and water in the pore spaces (Ratay [4]). A recent tunnel project connecting the Port of Miami to the mainland used a 44-pipe ground freezing system to control flow in the highly permeable Biscayne Aquifer (Cho \& Judy [15]).

The risk of collapse due to concentrated, irregular loading on the tunnel walls after the ground thaws is a concern with the artificial ground freezing technique (Cho \& Judy [15]). To avoid potential collapse, Cho and Judy (2013) reports, engineers designed the dewatering system for the Port of Miami Tunnel to freeze tunnel segments incrementally, in six-foot ring sections for the mining two of the five cross passages. The freezing process required two months to complete before mining could begin (Cho \& Judy [15]). Heaving from the frozen soil mass is another potential problem with ground freezing. Prevention measures typically include the installation of heat pipes. In the construction of a new underground rail tunnel in New York City, a system of heat pipes was placed above the crown to successfully control heaving (Ziegler et al. [16]). The result was only $13 \mathrm{~mm}$ of heave occurring during the freeze and pre-excavation period, eliminating the need for grouting. Steel support frames were used in the Port of Miami tunnel to prevent deformation of the temporary tunnel lining due to heaving (Cho \& Judy [15]).

Another potential issue associated with ground freezing in the presence of high groundwater velocities which can inhibit formation of a cohesive frozen wall. In these cases, it is sometimes necessary to raise the local water table to prevent water from flowing over the frozen wall. Commonly used in deep tunnel applications, frozen walls have been effective dewatering tools for depths up to $76 \mathrm{~m}$.

\section{Adverse Effects of Dewatering}

\section{Settlement}

Settlement is a leading concern associated with any dewatering program, especially if construction is near existing buildings or infrastructure. One extreme example occurred in the 1990s with the construction a large underground structure in Canada (Roy \& Robinson [17]). Consolidation settlement of the compressible silty clay soils produced settlements up to $360 \mathrm{~mm}$ at the site within 56 months of completion, and up to $200 \mathrm{~mm}$ settlements as far as $150 \mathrm{~m}$ north of the structure. Because the basement floor slab of the building was not designed to withstand water pressure, continuous pumping was required causing depressurization in the underlying confined aquifer. Groundwater recharging is often used in construction projects is to restore water levels, avoid settlement and consolidation of compressible soils. However, at this site, recharging efforts during construction stabilized the upper unconfined aquifer, but had no impact on the deeper confined aquifer (Roy \& Robinson [17]). It was later determined that engineers had not considered impacts on the lower confined aquifer in the initial dewatering design.

In an effort to avoid a potential catastrophe in the Port of Miami tunnel, an extensive geological investigation was conducted, lasting over two years, on the subsurface stratigraphy (Cho \& Judy [15]). Since no large-diameter tunnel had ever been bored though coralline limestone, a porous and unstable layer beneath the tunnel route, numerous samples and testing at U.S. and European laboratories was needed to fully understand the soil conditions and recommend strengthening measures before construction could commence (Cho \& Judy [15]).

Settlement issues are not limited to large-scale dewatering systems, smaller construction projects can produce similar problems. Drawdown during the construction of a $68 \mathrm{~cm}$ sanitary sewer main at a depth of 5.5 $\mathrm{m}$ below existing grade caused consolidation settlement up to $76 \mathrm{~mm}$ and extensive damage to a nearby residence $15 \mathrm{~m}$ from the construction trench (Mokwa et al. [18]). This case highlights the inherent uncertainty that exists when the subsurface stratigraphy is not fully known, and the damage that can occur to structures within close proximity of dewatered construction zones.

\section{Litigation}

Construction projects of any scope can be costly endeavors in themselves. Nonetheless, even a low-cost project can become financially impracticable when unexpected water problems arise during construction. Water issues alone can result in lengthy production delays that may result in complete re-designs of structures or construction methods (Abdul-Rahman et al. [1]; Powers et al. [5]).

Dewatering systems can be costly, not only to implement, but also after construction has been completed in terms of resulting settlement damage. Insurance claims and litigation related to groundwater issues are disproportionately high (Powers et al. [5]), and increasing. By 2003, more than $50 \%$ of insurance claims in Canada were associated with subsurface site conditions, especially relating to the resulting effects on surrounding buildings (Peaker [2]). Peaker [2] notes that in areas where dewatering is uncommon, issues during construction are more prevalent as contractors are less experienced with groundwater control measures. Field knowledge is an integral part of a successful dewatering program. Nevertheless, geotechnical consultants have often added general, or "boilerplate" recommendations to contract documents as a blanketed means of protection should dewatering become needed on a project (Peaker [2]). This practice, Peaker [2] argues, has resulted in contractors submitting lower bids based on the assumption that low-cost methods of dewatering will be sufficient. Ensuing changes orders arise when more extensive groundwater controls measures are required, adding to project delays and overall cost.

Considerable uncertainty exists related to groundwater in both the design and construction arenas. Over time, more of the liability for groundwater issues has shifted to geotechnical design engineers. From changes in Canadian laws in the 1980s, engineers are now more legally responsible for unforeseen complications that arise during and post-construction that are associated with subsurface conditions in Canada (Peaker [2]). To reduce the number of claims, Peaker [2] suggests more detailed geotechnical investigations should occur with sealed piezometers monitored over time to establish true groundwater tables and to reduce uncertainty.

Although thorough geotechnical investigations may help to reduce unanticipated groundwater issues during construction, inadequate design and construction methods, 
especially for critical processes, can also be costly and detrimental to the success of a project. In a case study by Ren et al. [7], problems encountered during the construction of a $\$ 60$ million storm water drainage project led to extreme delays and cost millions in damages. During the first phase of the project, the fine sands in the area leaked through the sheet piles and many started to collapse requiring backfill to prevent damage to adjacent roads and houses (Ren et al. [7]). Construction was further delayed by issues with settling pipes and subsequent damage. Although numerous factors contributed to the failure of this project, delays were primarily attributed to inadequate design with a lack of qualified engineers and inappropriate initial construction methods (Ren et al. [7]).

Unpredicted delays during construction can result in unknown millions in additional costs. There are many factors that can contribute to production delays. In an effort to quantify causes of delays, Serag et al. [3] developed a statistical model to provide an objective approach for owners and contractors to reconcile differences and establish responsibilities. The model was based on common factors that can cause delays such as rain, dewatering, material problems, conflicts, rework, accidents, and design inaccuracies. Although the model concentrated on productivity loss in pipe work for roadway projects due to change orders, similar models may be used in the future to not only reduce project costs, but also establish legal responsibilities.

\section{Discussion}

In construction, all parts must work together to be successful. Complex dewatering systems are best designed prior to construction. Nevertheless, even the most effective dewatering system must rely on astute contractors and field observations to make improvements as necessary once the system is operational. Better assessments of hydrogeological formations will undoubtedly cost additional time and money, but may help mitigate potential groundwater control problems. Based on the current research, it is evident that a thorough knowledge of subsurface conditions and formations is a key element to the success of a project. This assessment is best stated by the leading dewatering expert, J. Patrick Powers, P.E. [5]:

"There is a need for professionalism in addressing groundwater concerns. We must understand the patterns of groundwater movement at the individual site and appreciate water's effect on the particular soils involved, for those are two factors in the equation: how water moves in the soil and what water does to the soil. To the degree we understand these factors, our efforts to deal with groundwater will be more likely to succeed. (p. 3)"

Dewatering is simply one tool used in construction to complete the primary goal, an underground structure. Techniques used to suspend or remove groundwater discussed in this paper, as well as other methods, essentially depend on the subsurface hydrogeological characteristics of the project site. Inherent uniqueness of circumstances exists with each construction project. Therefore, it is reasonable to assume that combinations of several dewatering methods are typically employed as needed to complete construction.

Analytical models for selecting an appropriate dewatering system and risk assessment may offer designers and contractors an additional tool for large to small-scale construction operations (Ye et al. [19]; Jurado et al. [12]; Golestanifar \& Ahangari [20]). Numerical modeling software, such as MODFLOW, a three-dimensional groundwater flow program developed by the U.S. Geological Survey (USGS), that simulates the drawdown characteristics of dewatering systems, also can be advantageous (Hassan et al. [21]). These computer based tools may not be currently utilized in the transportation construction industry, or for other vital infrastructure such as deep utility installations, as with the sanitary sewer main discussed by Mokwa et al. [18].

The objective of this paper was to research groundwater control issues that occurred during the construction of various types of transportation facilities. Prevailing literature on the subject is minimal, generally discussing extreme cases stretching over many years. This may be due to the general nature of construction, where problems are quickly addressed to avoid costly delays in order to reach the ultimate goal. Unless a groundwater problem is catastrophic to the project, on-site changes are made and work continues. Additionally, successful dewatering programs used by seasoned contractors may also be considered proprietary in nature, and therefore not divulged to maintain industry competitiveness. However, the lack of published case studies on groundwater control measures, may contribute to "lessons learned" being repeated in the industry.

The methods of dewatering mentioned in this paper highlight the more common techniques in use today. Because construction, in general, is uniquely project specific, it is difficult to compare various dewatering methods, relating transportation construction to other construction industries. Nonetheless, documented experiences with groundwater control issues can be related to construction efforts across all industries such that lessons learned in other industries related to dewatering can be useful to transportation engineers and contractors.

\section{Conclusions}

More building and transportation structures are being constructed today in areas where high ground water tables precluded construction years before. To control groundwater during the construction process, various dewatering techniques are designed depending heavily on the amount of water to be removed, the subsurface profile at the site, and the underlying hydrological chacteristics. A review of common dewatering systems and methods used in the construction of transportation facilities found that similar techniques are used in other industries. A common thread among all construction initiatives is the need for thorough subsurface site investigation. The uncertainty of subsurface conditions has resulted in insurance claims and litigation due to groundwater issues to reach disproportionately high numbers in construction contracting. Better assessments of hydrogeological formations may help to mitigate potential groundwater control problems. As an aide to engineers and contractors, more published documentation on dewatering methods used in construction projects of varying scope would be beneficial. More research detailing case study dewatering systems for transportation projects is also needed and should be collected to avoid "lessons learned" in the future. 


\section{References}

1. Abdul-Rahman, H., Berawi, M.A., Berawi, A.R., Mohamed, O., Othman, M. \& Yahya, I.A. (2006). Delay Mitigation in the Malaysian Construction Industry. Journal of Construction Engineering and Management, ASCE, 132(2): 125-133.doi: 10.1061/ASCE0733-93642006132:2125

2. Peaker, S. (2003). Minimizing geo-exposure through comprehensive investigation. Journal of Professional Issues in Engineering Education and Practice, 129(2), 77-79.

3. Serag, E., Oloufa, A., \& Malone, L. (2008). Reconciliation of owner and contractor views in heavy construction projects. Journal of Professional Issues in Engineering Education and Practice, (1), 128-137. Doi: 10.1061/ASCE1052-39282008134:1128

4. Ratay, R. T. (2012). Temporary structures in construction ( $3^{\text {rd }}$ ed.). ISBN 978-0-07-175-175307-4. McGraw-Hill.

5. Powers, J. P., Corwin, A. B., Schmall, P. C., \& Kaeck, W. E. (2007). In Herridge C. J., Morris M. D. (Eds.), Construction dewatering and groundwater control; new methods and applications ( $3^{\text {rd }}$ ed.). John Wiley \& Sons, Inc., Hoboken, NJ.

6. Brown, J. L. (2002). Landmarks in American Civil Engineering History. Civil Engineering, 72 (11): 92-171.

7. Ren Z., Shen, G. Q. \& Xue, X.L. (2013). Failure Caused by Inadequate Construction Methods: An Expensive Lesson. Journal of Management in Engineering. ASCE, 29(1), 25-34. Doi: 10.1061/(ASCE)ME.1943-5479.0000117

8. Kiziltas S. and Akinci, B. (2009). Contextual information requirements of cost estimators from past construction projects. Journal of Construction Engineering and Management, ASCE, 135(9): 841-852. Doi: 10.1061/ASCECO.1943-7862.0000053

9. Lescohier, J. (2012). "Come Prepared to Rent the Right Pump". May 11 ,

2012. http://www.forconstructionpros.com/article/10713025/questions-toask-customers-before-they-rent-a-pump. Retrieved April 2014.

10. Cyr, R. Y., \& Chaisson, P. (1999). Modeling subsoil drainage systems for urban roadways. Canadian Journal of Civil Engineering, 26(6), 799-809.

11. Driscoll (1986). Groundwater and Wells, Johnson Division, St. Paul, Minnesota, USA.
12. Jurado, A., De Gaspari, F., Vilarrasa, V., Bolster, D., Sanchez-Vila, X., Fernandez-Garcia, D., \& Tartakovsky, D. M. (2012). Probabilistic analysis of groundwater-related risks at subsurface excavation sites. Engineering Geology, 125, 35-44. doi:http://dx.doi.org/10.1016/j.enggeo.2011.10.015

13. Mansur, C. I., \& Durrett, S. G. (2002). Dewatering cofferdam for construction of olmsted locks. Journal of Geotechnical and Geoenvironmental Engineering, 128(6), 496-510.

14. Keeping water out. (2013). Concrete International, 55-57. Retrieved from

http://search.proquest.com/docview/1350374235?accountid=14690.

15. Cho, A. \& Judy, S. (April 3, 2013). Port of Miami tunnel project features big challenges. Engineering News-Record, 04/08/2013. Retrieved from http://enr.construction.com/ infrastructure/transportation/2013/0408-port-of-miami-tunnelproject-features-big-challenges.asp

16. Ziegler, G.T., Rooney, P., \& Schmall, P.C. (2013). Ground freezing resolves complex challenges ahead of SEM tunneling. Mining Engineering, T\&UC, 36-41.

17. Roy, D., \& Robinson, K. E. (2009). Surface settlements at a soft soil site due to bedrock dewatering. Engineering Geology, 107(34), 109-117.

18. Mokwa, R. L., Mokwa, L. P., \& Mokwa, T. P. (2011). A case study on construction dewatering-induced settlement damage: Could this have been avoided? Journal of Civil Engineering and Architecture, 5(8), 670-678.

19. Ye, X. W., Ran, L., Yi, T. H., \& Dong, X. B. (2012). Intelligent risk assessment for dewatering of metro-tunnel deep excavations. Mathematical Problems in Engineering, doi:http://dx.doi.org/10.1155/2012/618979

20. Golestanifar, M., \& Ahangari, K. (2012). Choosing an optimal groundwater lowering technique for open pit mines. Mine Water and the Environment, 31(3), 192-198. doi:http://dx.doi.org/10.1007/s10230-012-0196-2

21. Hassan, N.A.A., Kotb, A., Hassan, A.A.A., \& Hagras, M.A. (2012). Dewatering using groundwater modelling in Al-Fustat area, Old Cairo, Egypt. Ain Shams Engineering Journal. 3 (4), 349-358. 